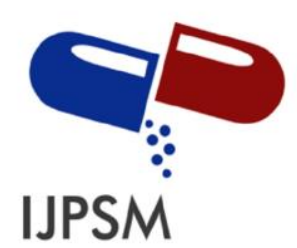

Erlinda Nengsih et al, Int. Journal of Pharmaceutical Sciences and Medicine (IJPSM),

Vol.6 Issue. 8, August- 2021, pg. 32-41

ISSN: 2519-9889

Impact Factor: 3.426

\title{
Review: Antioxidant Activity Test of Various Types of Mangroves
}

\author{
Erlinda Nengsih $^{1}$; Aried Eriadi ${ }^{1}$; Anzharni Fajrina ${ }^{1}$ \\ School of Pharmaceutical Science (STIFARM) Padang 25174, Indonesia \\ e-mail: erlindanengsih@gmail.com \\ DOI: 10.47760/ijpsm.2021.v06i08.003
}

\begin{abstract}
Free radicals are reactive oxygen that have unpaired electrons looking for partners by binding to electron molecules in the vicinity. Free radicals can cause several degenerative diseases such as diabetes, atherosclerosis, Parkinson's disease, Alzheimer's disease. The content of secondary metabolites in mangroves has the potential to prevent various diseases. Several methods commonly used to estimate the presence of antioxidants in plants include DPPH (2,2-diphenyl-1picrylhydrazyl), FRAP (ferrous reducing antioxidant power), and ABTS (2,2-azinobis-3-ethylbenzothiazole-6-sulfonic acid). The results of recent studies showed that some mangrove plants have antioxidant activity including: Rhyzophora mucronata, Nypa fruticans, Avicennia marina, Sonneratia alba, Acanthus ilicifolius L, Acrostichum aureum dan Scaevola taccada. Mangrove plants that have the highest $\mathrm{IC}_{50}$ value were found in leaves (methanol extract). The antioxidant activity of mangrove plants is caused by the presence of secondary metabolites contained in the extract such as flavonoids, phenolics, saponins, and tannins.
\end{abstract}

Keywords: Free radicals, Antioxidant, mangrove

\section{Introduction}

Free radicals are defined as molecules or molecular fragments containing one or more unpaired electrons in their outmost atomic or molecular orbitals [1]. An unpaired electron results in certain common properties that are shared by most radicals. Many radicals are unstable and highly reactive. Free radicals are divided into two types known as ROS (reactive oxygen species) and RNS (reactive nitrogen species). In the human body, free radicals come from endogenous and exogenous sources [3]. The exogenous sources include mainly environmental radiations and man-made sources while endogenous such as respiration, phagocytosis, intoxication, and fatty acid metabolism [4]. Around 10000-20000 free radicals attacking every cell every day including for health which enables the human body to fight inflammation, kill bacteria, controls smooth muscles which regulate the proper functioning of internal organs and blood vessels [1].

Antioxidants are divided into two types of natural antioxidants and synthetic antioxidants. Natural antioxidants come from fruits and plants while synthetic antioxidants such as BHA (butylated hydroxy aniline) and BHT (butylated toluene) have a carcinogenic effect, therefore the use of natural antioxidants has increased and is considered safer because it comes from natural ingredients [5]. 


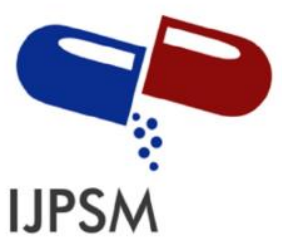

\section{Erlinda Nengsih et al, Int. Journal of Pharmaceutical Sciences and Medicine (IJPSM), Vol.6 Issue. 8, August- 2021, pg. 32-41}

Antioxidants are substances that are at low concentrations compared with the oxidizable substrate, significantly inhibit or prevent oxidation of the substrate. The term oxidizing substrate includes almost everything found in living cells including lipids, proteins, and DNA [6]. An antioxidant is a molecule that can prevent or slow the oxidation of macromolecules. The role of antioxidants is to lower or terminate these chain reactions by removing free radicals or inhibiting other oxidation reactions by being oxidized themselves. So, antioxidants are often reducing agents [7].

Mangroves are plants that are rich in bioactive compounds and can be used as an antioxidant [8]. The mangrove forest is a forest species that are along the coast or a river that is affected by the tide. mangroves have the potential as a high source of bioactive compounds such as polyphenols, flavonoids, anthocyanins, vitamins, antibiotics, and antioxidants [9].

Several mangrove species exhibit antioxidant activity such as Rhizophora mucronata, Avicennia marina, Sonneratia alba, Sonneratia caseolaris L, nypa fructicaris, Acantus ilicifoliu, Acrostichum aureum, Ceriops decandra, Aegiceras corniculatum L, Bruguiera cylindrical, Kandelia candel, Rhyzophora stylosa, Xylocarpus moluccensis, Scaevola taccada, Hirietera Fomes.

The efficacy of mangrove plants as medicine has been widely used by the community, to treat diabetes, hypertension, wounds, digestive disorders, and cancer. The parts of the mangrove plant that are used as treatment are leaves, fruit, and sap [10]. Secondary metabolites in mangroves are known to have pharmacological activity or treat various diseases. All the pharmacological effects found in mangrove plants cannot be separated from their role as antioxidants.

\section{Data Collection}

This review article was created using literature study techniques by finding sources or literature in the form of primary data were collected from pharmaceutical official books or national and international journals in the last 20 years (2000-2020). The literature was collected from trusted online journal sites such as Google Scholar, Elsevier, and other E-resource with the keywords "mangrove" and "antioxidant".

\section{Analysis Method}

\section{DPPH Method (2,2-diphenyl-1-picrylhydrazyl )}

DPPH is a free radical that can react with a compound that donates a hydrogen atom can be useful to test the antioxidant activity. DPPH is the most commonly used method to measure the antioxidant activity of plants. In addition, the DPPH method is very simple, inexpensive, accurate, and fast to test the ability of radical compounds [11].

\section{FRAP Method (Ferric Reducing Antioxidant Power)}

The FRAP method is a method that was used for testing antioxidants in plants. This method can determine the antioxidant content using spectrophotometry. The FRAP method has several advantages such as easy to create a reagent, cheap, fast and simple. This method can determine the total antioxidant content of a material based on the ability of the compound to reduce $\mathrm{Fe} 3+$ ions to $\mathrm{Fe} 2+$, therefore the antioxidant capacity of the compound is the same as the ability to reduce the compound [12]. 


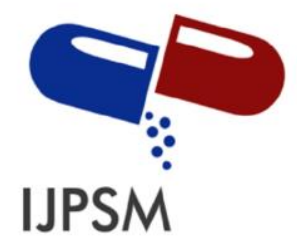

Erlinda Nengsih et al, Int. Journal of Pharmaceutical Sciences and Medicine (IJPSM),

Vol.6 Issue. 8, August- 2021, pg. 32-41

ISSN: 2519-9889

Impact Factor: 3.426

\section{ABTS Method (2,2 -Azinobis -3-ethylbenzothiazoline-6-sulphonic acid)}

ABTS is a radical compound containing a nitrogen atom. Measurement of antioxidant activity was carried out based on the removal of the color of ABTS which was originally blue-green but would turn colorless when reduced by free radicals. This method can measure the number of free radicals with a fairly high level of sensitivity. ABTS method have several advantages such as easy to repeat, simple, fast and effective [13]. Antioxidant activity of various species of mangrove plants as shown in table 1 .

Table 1. Antioxidant Activities of Various Species of Mangrove Plants

\begin{tabular}{|c|c|c|c|c|c|c|c|}
\hline No & Species & Part of plant & Extract/Fraction & Concentration & $\begin{array}{c}\text { Test } \\
\text { method }\end{array}$ & Result & Reff \\
\hline 1. & $\begin{array}{l}\text { Sonneratia } \\
\text { caseolaris }\end{array}$ & Leaf & $\begin{array}{l}\text { Etanol extract } \\
\text { Non polar fraction } \\
\text { Semi polar } \\
\text { fraction } \\
\text { Polar fraction }\end{array}$ & $\begin{array}{c}60,70,80,90 \text { and } \\
100 \mathrm{ppm}\end{array}$ & FRAP & $\begin{array}{l}6.37 \mathrm{mgAAE} / \mathrm{g} \\
5.35 \mathrm{mgAAE} / \mathrm{g} \\
6.59 \mathrm{mgAAE} / \mathrm{g} \\
5.96 \mathrm{mgAAE} / \mathrm{g}\end{array}$ & [14] \\
\hline 2. & $\begin{array}{l}\text { Rhizopora } \\
\text { mucronata }\end{array}$ & Leaf & $\begin{array}{l}\text { Methanol extract } \\
\text { Ethylacetate } \\
\text { extract } \\
\text { N-hexane extract }\end{array}$ & $\begin{array}{l}50, \quad 100, \quad 150, \\
200, \quad 250, \quad 300, \\
350,400 \mathrm{ppm}\end{array}$ & DPPH & $\begin{array}{l}113.41 \mathrm{ppm} \\
184.78 \mathrm{ppm} \\
151.13 \mathrm{ppm}\end{array}$ & {$[15]$} \\
\hline 3. & $\begin{array}{l}\text { Nypa } \\
\text { fruticans }\end{array}$ & Leaf & $\begin{array}{l}\text { Ethylacetate } \\
\text { extract } \\
\text { Methanol extract } \\
\text { N-hexane extract } \\
\text { N-hexane fraction } \\
\text { Ethylacetate } \\
\text { fraction } \\
\text { Methanol fraction }\end{array}$ & $1000 \mathrm{ppm}$ & DPPH & $\begin{array}{l}26.81 \pm 1.75 \mathrm{ppm} \\
17.72 \pm 0.107 \mathrm{ppm} \\
52.86 \pm 2.849 \mathrm{ppm} \\
\\
\\
22.03 \pm 0.74 \mathrm{ppm} \\
24.67 \pm 0.41 \mathrm{ppm} \\
22.91 \pm 2.04 \mathrm{ppm}\end{array}$ & [16] \\
\hline
\end{tabular}




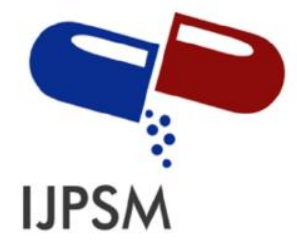

Erlinda Nengsih et al, Int. Journal of Pharmaceutical Sciences and Medicine (IJPSM),

Vol.6 Issue. 8, August- 2021, pg. 32-41

ISSN: 2519-9889

Impact Factor: 3.426

\begin{tabular}{|c|c|c|c|c|c|c|c|}
\hline 4. & $\begin{array}{l}\text { Avicennia } \\
\text { marina }\end{array}$ & $\begin{array}{l}\text { Leaf } \\
\text { Bark }\end{array}$ & $\begin{array}{l}\text { Methanol extract } \\
\text { Methanol extract }\end{array}$ & $\begin{array}{l}31,25,62.5, \\
125,250 \mathrm{ppm}\end{array}$ & DPPH & $\begin{array}{l}123.23 \mathrm{ppm} \\
198.15 \mathrm{ppm}\end{array}$ & [17] \\
\hline 5. & $\begin{array}{l}\text { Sonneratia } \\
\text { alba }\end{array}$ & Leaf & Methanol extract & $20,40,60,80 \%$ & DPPH & $39.95 \mathrm{ppm}$ & [18] \\
\hline 6. & $\begin{array}{l}\text { Acanthus } \\
\text { ilicifolius } L .\end{array}$ & Leaf & $\begin{array}{l}\text { N-hexane extract } \\
\text { Ethyl acetate } \\
\text { extract } \\
\text { Ethanol extract }\end{array}$ & $\begin{array}{l}20,40,60,80 \\
\text { dan } 100 \mathrm{ppm} .\end{array}$ & DPPH & $\begin{array}{l}361.730 \mu \mathrm{g} / \mathrm{ml} \\
162.512 \mu \mathrm{g} / \mathrm{ml} \\
34.659 \mu \mathrm{g} / \mathrm{ml}\end{array}$ & [19] \\
\hline 7. & $\begin{array}{l}\text { Acrostichum } \\
\text { aureum }\end{array}$ & Leaf & Methanol extract & $\begin{array}{l}12,5 ; 25 ; 50 ; \\
100 \text { dan } 200 \\
\text { ppm }\end{array}$ & DPPH & $29.5303 \mathrm{ppm}$ & {$[20]$} \\
\hline 8. & $\begin{array}{l}\text { Ceriops } \\
\text { decandra }\end{array}$ & Bark & Ethanol extract & $\begin{array}{l}5, \quad 10, \quad 20,40, \\
60,80,100 \mu \mathrm{g} / \\
\mathrm{ml}\end{array}$ & DPPH & $\begin{array}{l}12.90 \pm 0.972 \mu \mathrm{g} / \\
\mathrm{ml}\end{array}$ & [21] \\
\hline 9. & $\begin{array}{l}\text { Aegiceras } \\
\text { corniculatu } \\
m \mathrm{~L}\end{array}$ & $\begin{array}{l}\text { Leaf } \\
\text { Bark }\end{array}$ & $\begin{array}{l}\text { Methanol extract } \\
\text { Water extract } \\
\text { Ethyl acetate } \\
\text { extract } \\
\text { Petroleum ether } \\
\text { extract } \\
\text { Methanol extract } \\
\text { Water extract } \\
\text { Petroleum ether }\end{array}$ & $\begin{array}{l}\text { 100, 150, dan } \\
200 \mu \mathrm{g} / \mathrm{ml}\end{array}$ & DPPH & $\begin{array}{l}55.77 \mu \mathrm{g} / \mathrm{ml} \\
58.43 \mu \mathrm{g} / \mathrm{ml} \\
59.73 \mu \mathrm{g} / \mathrm{ml} \\
328 \mu \mathrm{g} / \mathrm{ml} \\
80.73 \mu \mathrm{g} / \mathrm{ml} \\
82.02 \mu \mathrm{g} / \mathrm{ml}\end{array}$ & [22] \\
\hline
\end{tabular}




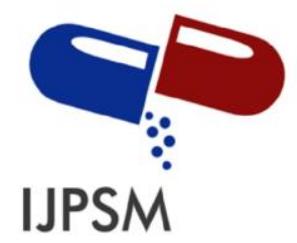

Erlinda Nengsih et al, Int. Journal of Pharmaceutical Sciences and Medicine (IJPSM),

Vol.6 Issue. 8, August- 2021, pg. 32-41

ISSN: 2519-9889

Impact Factor: 3.426

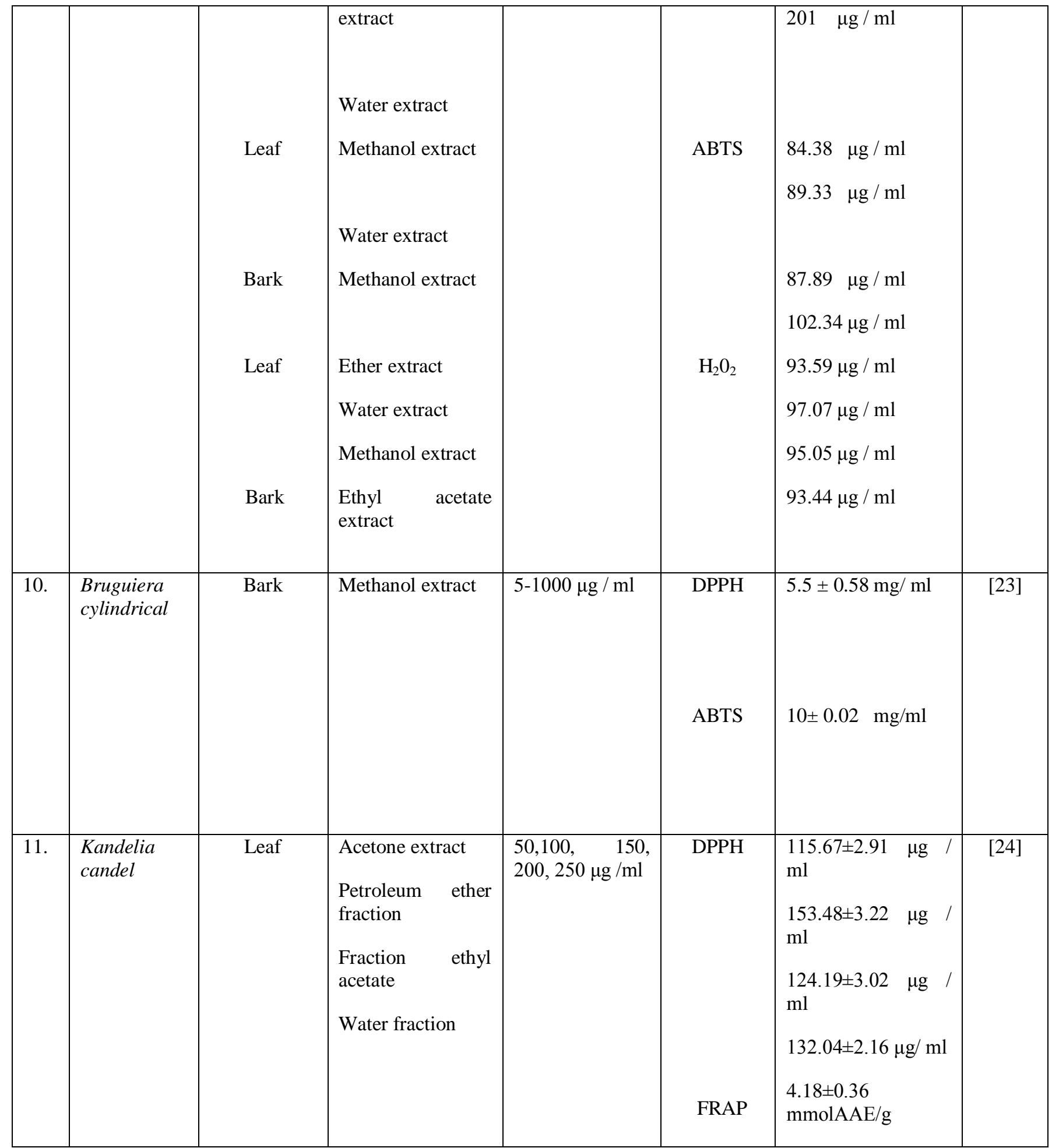




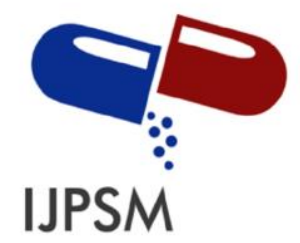

Erlinda Nengsih et al, Int. Journal of Pharmaceutical Sciences and Medicine (IJPSM),

Vol.6 Issue. 8, August- 2021, pg. 32-41

ISSN: 2519-9889

Impact Factor: 3.426

\begin{tabular}{|c|c|c|c|c|c|c|c|}
\hline & & & & & & $\begin{array}{l}2.99 \pm 0.27 \\
\text { mmolAAE/g } \\
\\
4.39 \pm 0.17 \\
\text { mmolAAE } / \mathrm{g} \\
\\
3.69 \pm 0.04 \quad \mathrm{mmol} \\
\mathrm{AAE} / \mathrm{g}\end{array}$ & \\
\hline 12. & $\begin{array}{l}\text { Rhyzophora } \\
\text { stylosa }\end{array}$ & $\begin{array}{l}\text { Leaf } \\
\text { Root }\end{array}$ & $\begin{array}{l}\text { Methanol extract } \\
\text { Ethylacetate } \\
\text { extract, } \\
\text { N-hexane extrac } \\
\text { Methanol extract }\end{array}$ & $\begin{array}{l}5,10,15,20, \\
25,30 \mu \mathrm{g} / \mathrm{ml}\end{array}$ & $\overline{\mathrm{DPPH}}$ & $\begin{array}{l}5.01 \mathrm{ppm} \\
8.51 \mathrm{ppm} \\
33.14 \mathrm{ppm} \\
2.55 \mathrm{ppm}\end{array}$ & [25] \\
\hline 13. & $\begin{array}{l}\text { Xylocarpus } \\
\text { moluccensis }\end{array}$ & Bark & Methanol extract & $\begin{array}{l}10,25,50,75 \\
100 \mathrm{ppm}\end{array}$ & DPPH & $26.189 \mathrm{ppm}$ & $\begin{array}{l}{[26]} \\
\end{array}$ \\
\hline 14. & $\begin{array}{l}\text { Scaevola } \\
\text { taccada }\end{array}$ & Leaf & $\begin{array}{l}\text { Methanol extract } \\
\text { Chloroform } \\
\text { extract } \\
\text { Chloroform } \\
\text { extract } \\
\text { Methanol extract }\end{array}$ & $\begin{array}{l}200,400, \\
600 \mathrm{ppm}\end{array}$ & DPPH & $\begin{array}{l}0.1034 \mathrm{ppm} \\
0.1944 \mathrm{ppm} \\
\\
\\
0.4640 \mathrm{ppm} \\
0.4653 \mathrm{ppm}\end{array}$ & {$[27]$} \\
\hline 15. & $\begin{array}{l}\text { Hirietera } \\
\text { Fomes }\end{array}$ & Leaf & Acetone extract & $25-200 \mu \mathrm{g} / \mathrm{ml}$ & $\begin{array}{c}\text { DPPH } \\
\mathrm{H}_{2} \mathrm{O}_{2}\end{array}$ & $\begin{array}{l}182.43 \mu \mathrm{g} / \mathrm{ml} \\
71.991 \mu \mathrm{g} / \mathrm{ml}\end{array}$ & {$[28]$} \\
\hline
\end{tabular}

Crabapple mangrove (Sonneratia caseolaris) has bioactive compounds such as flavonoids, steroids, phenol hydroquinone, and tannins [29]. Sonneratia caseolaris has antioxidant activity based on testing using the FRAP method. This method can be used to test the antioxidant activity of plants. The FRAP method has several advantages such as cheap, easy to create a reagent, cheap, simple, and fast [30]. The principle of this FRAP 


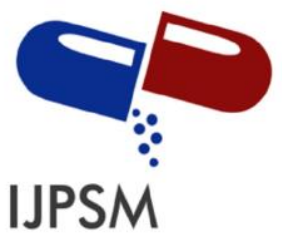

\section{Erlinda Nengsih et al, Int. Journal of Pharmaceutical Sciences and Medicine (IJPSM), Vol.6 Issue. 8, August- 2021, pg. 32-41}

ISSN: 2519-9889

Impact Factor: 3.426

method is the ability of antioxidant compounds to reducing Fe3+ ions to Fe2+. The antioxidant ability of a compound is analogous to the reducing ability of the compound [31]. The results of the study of antioxidant activity of ethanol extract of leaves of semipolar and polar fraction showed a value of 5:35; 6.59; and 5.96 mgAAE/g [14].

Rhizophora mucronata is a type of mangrove that has the potential as a source of natural antioxidants. Antioxidant activity was measured by using the DPPH method. The DPPH test on the methanol extract of Rhizophora mucronata leaves had an IC50 value of $151.41 \mathrm{ppm}$, ethyl acetate extract $187.78 \mathrm{ppm}$, and nhexane extract $151.13 \mathrm{ppm}$. based on the results of these studies the methanol extract of the leaves has the highest antioxidant activity compared to the ethyl acetate extract and n-hexane. This is related to the chemical content in each extract such as the total phenolic content, chlorophyll A, chlorophyll B, and carotenoids [15].

Nypa fruticans have antioxidant activity based on DPPH testing. DPPH test on ethyl acetate extract of nipa leaves showed an IC50 value of $26.81 \pm 1.75 \mathrm{ppm}$, while the $\mathrm{n}$-hexane fraction from nipa seeds IC50 value was $22.03 \pm 0.74 \mathrm{ppm}$. The results of this study showed that the methanol extract of Nipah leaves has high antioxidant activity with an IC50 value of $17.72 \mathrm{ppm}[16]$.

The antioxidant activity of Avicennia marina was tested on leaves and bark using the DPPH method. Leaves and bark were extracted with methanol solvent. The results showed that the methanol extract of Avicennia marina leaves showed the highest IC50 value of $123.23 \mathrm{ppm}$, while the methanol extract of Avicennia marina bark showed the lowest IC50 value of 198.15 ppm [17]. Avicennia marina contains bioactive compounds can be used to treat a variety of diseases such as antioxidants, anticonvulsant, anti-inflammatory and antiallergic [32].

Sonneratia alba contains secondary metabolites, namely flavonoids that can act as antioxidants. The antioxidant activity of Sonneratia alba leaf extract was carried out by DPPH assay. The DPPH test on the methanol extract of Sonneratia alba leaves has an IC50 value of $39.95 \mathrm{ppm}$. Therefore, methanol extract of Sonneratia alba leaf can counteract or inhibit free radicals [18].

Acanthus ilicifolius L. is known to contain bioactive compounds such as flavonoids, steroids, terpenoids, and ligands [33]. Antioxidant activity of Acanthus ilicifolius L leaves using the DPPH method. The DPPH test on the n-hexane extract of daruju leaves showed an IC50 value of $361,730 \mathrm{~g} / \mathrm{mL}$, ethyl acetate extract had an IC50 value of $162,512 \mathrm{~g} / \mathrm{mL}$, while the ethanol extract of daruju leaves had an IC50 value of $34,659 \mathrm{~g} / \mathrm{mL}$. The results of this study indicate that the ethanol extract of daruju leaves has the highest antioxidant activity compared to n-hexane extract and ethyl acetate extract [19].

Acrostichum aureum contains chemicals such as phenolics, flavonoids, and antioxidants [34]. The antioxidant activity of the ethanolic extract of Acrostichum aureum leaves was tested using the DPPH method. The results showed the highest IC50 value was 29.5303 ppm [20].

The antioxidant activity of Ceriops decandra bark was tested using the DPPH method. Ceriops decandra bark was extracted with ethanol. The results showed that the antioxidant activity of the ethanol extract of Ceriops decandra bark with an IC50 value of $12.90 \mu \mathrm{g} / \mathrm{ml}$. This is due to the presence of flavonoids and tannins in Ceriops decandra plants which affect antioxidant activity [21].

Aegiceras corniculatum L. (leaves and bark) were tested for antioxidant activity using various methods such as DPPH, ABTS, and H202. The leaves and bark of Aegiceras corniculatum L. were extracted with several solvents such as methanol, water, ethyl acetate, and petroleum ether. The results of the DPPH method showed that the methanol, water, ethyl acetate, and petroleum ether extracts of leaves were EC50: 55.77; 58.43; 59.73; $328 \mathrm{~g} / \mathrm{ml}$, respectively. Methanol, water, and petroleum ether extracts of bark showed an EC50 value of 80.73; 


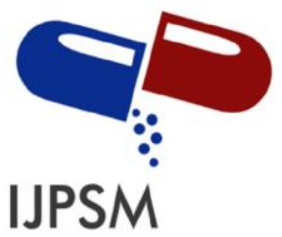

\section{Erlinda Nengsih et al, Int. Journal of Pharmaceutical Sciences and Medicine (IJPSM), Vol.6 Issue. 8, August- 2021, pg. 32-41}

ISSN: 2519-9889

Impact Factor: 3.426

82.02; and $201 \mathrm{~g} / \mathrm{ml}$. The ABTS test showed water and methanol extract of leaves of Aegiceras corniculatum L. with EC50 values of 84.38 and $89.33 \mathrm{~g} / \mathrm{ml}$ and water and methanol extract of bark with EC50 value 87.89 and $102.34 \mathrm{~g} / \mathrm{ml}$. While the H202 method of petroleum ether, water, and methanol extract of leaf obtained the EC50 value of $93.59,97.07$, and $95.05 \mathrm{~g} / \mathrm{ml}$. the ethyl acetate extract of the bark showed the value of EC50 $93.44 \mathrm{ug} / \mathrm{ml}$. The results showed that the antioxidant activity of the methanol and ethyl acetate extracts showed the highest antioxidant activity, while the petroleum ether extract showed the lowest antioxidant activity [22].

Bruguiera cylindrical bark was tested for antioxidant activity using DPPH and ABTS methods. Bruguiera cylindrical bark contains flavonoid and phenolic compounds. Bruguiera cylindrical bark extracted using methanol. The antioxidant activity of methanol extract from Bruguiera cylindrical bark showed DPPH EC50 values of $5.5 \pm 0.58 \mathrm{~g} / \mathrm{ml}$ and ABTS $10 \pm 0.02 \mathrm{~g} / \mathrm{ml}$. The results of the study reported that the methanol extract of Bruguiera cylindrical bark showed high results against the antiradical activity of DPPH [23]. To determine the antioxidant activity of plants, the DPPH free radical method is commonly used. DPPH is a stable free radical and is also commonly used to evaluate the antioxidant activity of several compounds or natural materials. The purpose of this method is a concentration parameter that gives the effect of 50\% (IC50).

The antioxidant activity of Kandelia candel was investigated by DPPH and FRAP assays. Acetone extract and its fractions from petroleum ether, water, and ethyl acetate of Kandelia candel leaves tested by DPPH assay showed that $70 \%$ acetone extract had an antioxidant activity with an IC50 value of $115.67 \pm 2.91 \mathrm{~g} / \mathrm{ml}$, petroleum ether fraction IC50 $153.48 \pm 3.22 \mathrm{~g} / \mathrm{ml}$, ethyl acetate fraction IC50 124.19 $\pm 3.02 \mathrm{~g} / \mathrm{ml}$ and water IC50 $132.04 \pm 2.1 \mathrm{~g} / \mathrm{ml}$, while the FRAP test of $70 \%$ acetone extract obtained values of $4.18 \pm 0.36 \mathrm{mmol} \mathrm{AAE} / \mathrm{g}$, petroleum ether $2.99 \pm 0.27$, ethyl acetate $4.39 \pm 0.17$ and water $3.69 \pm 0.04 \mathrm{mmol} \mathrm{AAE} / \mathrm{g}$. The results showed that all extracts and fractions had high antioxidant activity values [24].

Rhizophora stylose contains alkaloids, flavonoids, tannins, saponins which can be used as antibacterial and antioxidants [36]. Antioxidant activity of leave and root of Kandelia candel plant were investigated by the DPPH method. DPPH test on methanol extract of R. stylosa leaves showed an EC50 value of 5.01 ppm, ethyl acetate extract $8.51 \mathrm{ppm}$, and n-hexane extract an EC50 value of $33.14 \mathrm{ppm}$, while the methanol extract of $R$. stylose roots showed an EC50 value of $2.55 \mathrm{ppm}$. This result showed that the extracts of red mangrove leaves and roots have high antioxidant activity [25].

Xylocarpus moluccensis contains phenolic compounds such as flavonoids and saponins. The antioxidant activity of the methanol extract of Xylocarpus moluccensis bark was tested using the DPPH method. DPPH test on methanol extract of Xylocarpus moluccensis bark has highly reactive antioxidant with an IC50 value of $26,189 \mathrm{ppm}$. These results indicate that the methanol extract of mangrove bark has a very strong antioxidant activity with an IC50 value of $<50 \mathrm{ppm}[26]$.

Antioxidant activity of Scaevola taccada leaves and fruits were investigated by DPPH assay. Scaevola taccada leaves and fruits were extracted with methanol and chloroform as solvents. S. taccada contains phenolic compounds. Other compounds contained in S. taccada include amino acids, glycosides, carbohydrates, and proteins. DPPH test on methanol extract from S. taccada leaves showed an IC50 value of $0.1034 \mathrm{ppm}$ and chloroform extract had an IC50 value of $0.1944 \mathrm{ppm}$. While the methanol extract from S. taccada fruit had an IC50 value of $0.4653 \mathrm{ppm}$ and the chloroform extract had an IC50 value of $0.4640 \mathrm{ppm}$. The results of the study reported that the methanol extract of S. taccada leaves had high antioxidant activity. Good antioxidants are antioxidants that have IC50 values of less than 200 ppm [27].

Heritiera fomes belongs to the family Malvacea that contains phenolic and flavonoid compounds. The antioxidant activity of Heritiera fomes leaves was extracted in acetone was estimed by DPPH and hydrogen peroxide (H202). The acetonee extract of H. fomes leaves has shown antioxidant activity against DPPH with 


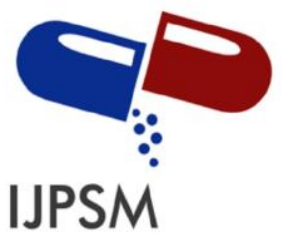

\section{Erlinda Nengsih et al, Int. Journal of Pharmaceutical Sciences and Medicine (IJPSM), Vol.6 Issue. 8, August- 2021, pg. 32-41}

ISSN: 2519-9889

Impact Factor: 3.426

IC50 of $182.43 \mu \mathrm{g} / \mathrm{ml}$, while the hydrogen peroxide test shows an IC50 value of 71,991 $\mathrm{g} / \mathrm{ml}$. Heritiera fomes leaves have a free radical scavenging effect that has the potential as a strong antioxidant [28].

\section{Conclusion}

Antioxidants are inhibitors that can prevent or slow cell damage caused by free radicals. Several methods commonly used to estimate the presence of antioxidants in plants include DPPH (2,2-diphenyl-1picrylhydrazyl), FRAP (ferrous reducing antioxidant power), and ABTS (2,2-azinobis-3-ethylbenzothiazole-6sulfonic acid). Leaves of mangrove plants that have high antioxidant activity, as evidenced by the DPPH assay including Rhyzophora mucronata, Nypa fruticans, Avicennia marina, Sonneratia alba, Acanthus ilicifolius $L$, Acrostichum aureum dan Scaevola taccada. A low value of inhibition concentration of 50\% (IC50) indicates a higher antioxidant activity. The antioxidant activity of mangrove plants is caused by the presence of secondary metabolites contained in the extract such as flavonoids, phenolics, saponins, and tannins.

\section{References}

[1] Qazi, M. A., Molvi, K. I. (2018). Free Radicals and their Management. American Journal of Pharmacy and Health Research, 6 (4),1-10.

[2] Lobo, V., Patil, A., Phatak, A., Chandra, N. (2010). Free Radicals, Antioxidants and Functional Foods: Impact on Human Health. Pharmacognosy Reviews, 4 (8), 118-26.

[3] Zulaikhah, S. T. (2017). The Role of Antioxidant to Prevent Free Radicals in The Body. Sains Medika, 8 (1), 3945.

[4] Thatoi, H. N., Patra, J. K., Das, S. K.(2013). Free Radical Scavenging and Antioxidant Potential of Mangrove Plants: A review. Acta Physiol Plant, 36 (3),1-15.

[5] Sangkala, S. A., Jura, M. R., Tangkas, I. M. ( 2014). Uji Aktivitas Antioksidan Ekstrak Buah Merah (Pandanus Baccari L) di Daerah Poso Sulawesi Tengah. J. Akad.Kim. 3(4), 198-205.

[6] Atta, E. M., Mohamed, N. H., Abdelgawad, A. A. M. (2017). Antioxidants: An Overview on the Natural and Synthetic Types. Eur. Chem. Bull, 6 (8), 365-375.

[7] Adwas, A. A., Elsayed, A. S. I., Azab, A. E., Quwaydir, A. F. (2019). Oxidative Stress and Antioxidant Mechanisms in Human Body. Journal of Applied Biotechnology Bioengineering, 6(1), 43-47.

[8] Winarti, Rahardja, B. S., Sudarno. (2019). Aktivitas Antioksidan Ekstrak Daun Mangrove Sonneratia caseolaris Berdasarkan Tingkat Kematangan Daun. Journal of Marine Coastal Science, 8 (3), 130-138.

[9] Thuoc, D. V.,Mai, N.T.N., Ha, L.T.V., Hung, L.D., Tra, D.H., Hung, N.K., Hung, N.P. (2018). Evaluasi Antibakteri, Antioksidan dan Aktivitas Antiobese dari Jus Buah Crabapple Mangrove Sonneratia caseolaris (Linn.). Jurnal Internasional Ilmu Pertanian dan Sunber Daya Alam, 5(2) ,25-29.

[10] Lubis, R., Nasution, J., Kardhinata, E. H. (2017). Kajian Etnobotani Tumbuhan Mangrove Oleh Masyarakat Kampung Nipah Dusun III Desa Sei Nagalawan Kecamatan Perbaungan Kabupaten Serdang Bedagai Sumatera Utara. Jurnal Biosains, 3 (1),9-13.

[11] Mariani, S., Rahman, N., Supriadi. (2018). Uji Aktivitas Antioksidan Ekstrak Buah Semangka (Citrullus lanatus). J Akademika Kim, 7 (3), 107-114.

[12] Ufrianto., Tamrin., Faradila, RH. F.(2019). Pemanfaatan Bahan-Bahan Alami yang Memiliki Aktivitas Antioksidan: Studi Kepustakaan. J. Sains dan Teknologi Pangan, 4 (1), 1982-1991.

[13] Cahyani, D. R., Tamrin, Faradilla, RH. F.(2020). Evaluasi Metode In Vitro Pada Analisis Aktivitas Antioksidan Beberapa Buah Tropis: Studi Kepustakaan. J. Sains dan Teknologi Pangan, 5 (6), 3465-3480.

[14] Raharjo, D., Haryoto. (2019). Antioxidant Activity of Mangrove Sonneratia caseolaris L using the FRAP Method. International Summit on Science Technology and Humanity, 1-7.

[15] Ridlo, A., Pramesti, R., Koesoemadji., Supriyantini, E., Soenardjo, N.(2017). Aktivitas Antioksidan Ekstrak Daun Mangrove Rhizopora mucronata. Buletin Oseanografi Marina, 6 (2), 110-116.

[16] Putri, I. J., Fauziyah., Elfita. (2013). Aktivitas antioksidan Daun dan Biji Buah Nipah (Nypa fructicans) Asal Pesisir Banyuasin Sumatera Selatan Dengan Metode DPPH. Maspari Journal, 5 (1), 16-21.

[17] Iranawati, F., Muhammad, F., Fajri, H., Kasitowati, RD, Arifin, S. (2017). The potential of Mangrove Avicennia Marina and A. Alb a from Nguling District, Pasuruan, East Java as an Antioxidant. IOP Conf. Series: Earth and 


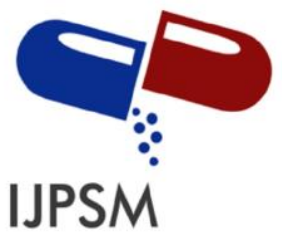

\section{Erlinda Nengsih et al, Int. Journal of Pharmaceutical Sciences and Medicine (IJPSM), Vol.6 Issue. 8, August- 2021, pg. 32-41}

Environmental Science, 137, 1-6.
Binuni, R., Maarisit, W., Hariyadi., Saroinsong, Y. (2020). Uji Aktivitas Antioksidan Ekstrak Daun Mangrove Sonneratia alba Dari Kecamatan Tagulandang, Sulawesi Utara Menggunakan Metode DPPH. Jurnal Biofarmasetikal Tropis, 3(1), 79-85.

[19] Handayani, S., Najib, A., Wati, N. P.(2018). Uji Aktivitas Antioksidan Ekstrak Daun Daruju (Acanthus ilicifolius L.) Dengan Metode Peredaman Radikal Bebas 1,1-Diphenyl-2-Picrylhidrazil (DPPH). Jurnal Fitofarmaka Indonesia, 5 (2), 299-308.

[20] Nurhasnawati, H., Sundu, R., Sapri., Supriningrum, R., Kuspradini, H., Arung, E.T. (2019). Antioxidant Activity, Total Phenolic and Flavonoid Content of Several Indigenous Species of Ferns in East Kalimantan, Indonesia. BIODIVERSITAS, 20 (2), 576-580.

[21] Hossain, H., Moniruzzaman, Sk., Nimmi, I., Kawsar, H., Hossain, A., Islam, A., Jahan, I. A.(2011). Antiinflammatory and Antioxidant Activities of the Ethanolic Extract of Ceriops decandra (Griff.) Ding Hou bark. Orient Pharm Exp Med, 11 (4), 215-220.

[22] Bidve, SC., VB, K., MR, S., Malpathak, NP. (2017). Antioxidant Potential of Bark and Leaves Extracts of Mangrove Plant Aegiceras corniculatum L. World Journal Pharmaceutical Research, 6 (13), 495-505

[23] Krishnamoorthy, M., Sasikumar, JM., Shamna, R., Pandiarajan, C., Sofia, P., Nagarajan, B.(2011). Antioxidant Activities of Bark Extract from Mangroves, Bruguiera cylindrica (L.) Blume and Ceriops decandra Perr. Indian Journal Pharmacology, 43 (5), 557-582.

[24] Wei, SD., Zhou, HC., Lin, YM.(2010). Antioxidant Activities of Extract and Fractions from the Hypocotyls of the Mangrove Plant Kandelia candel. Interntional Journal of Molecular Sciences, 11 (10), 4080-4093.

[25] Hanapi, A., Fasya, G. A., Syakuro, A. (2019). Uji Aktivitas Antioksidan Ekstrak n-Heksana, Etil Asetat, Metanol Daun dan Akar Bakau Merah (Rhyzophora stylosa) dengan Metode DPPH. Journal of Chemistry, 7 (1), $20-24$.

[26] Putri, A. A. S., Hidajati, N. (2015). Uji Aktivitas Antioksidan Senyawa Fenolik Ekstrak Metanol Kulit Batang Tumbuhan Nyiri Batu (Xylocarpus moluccensis). UNESA Journal of Chemistry, 4 (1),37-42.

[27] Rudianto., Putri, R. M. S., Apriandi, A. (2019). Aktivitas Antioksidan Dari Tanaman "Beruas Laut" ( Scaevola taccada ) Antioxidant analysis of Scaevola taccada (Beruas Laut). Marinade, 02 (01), 29-38.

[28] Kalyani, C., Tulasi, C. D. S. L. N., Sudarshan, S. M., Geetha, A., Narusu, M. L., Saida, L. (2020). Screening of Antimicrobial and Antioxidant Activity of Acetone Extracts of Heritiera fomes Whole Plant against Pathogens. International Journal of Pharmaceutical Investigation, 10 (4), 564-568.

[29] Putri, V. S.W., Yulita, V., Rijai, L.(2015). Aktivitas Antioksidan Kulit Buah Pidada Merah (Sonneratia Caseolaris L. .). Jurnal Sains dan Kesehatan, 1 (2), 69-74.

[30] Putri, M. D., Arumasi, A., Kurniaty, N.(2020). Review Artikel : Uji Aktivitas Antioksidan Ekstrak Daging Buah Semangka dan Albedo Semangka ( Citrullus Lanatus ) dengan Metode DPPH dan FRAP. Prosiding Farmasi, 6 (2), 992-997.

[31] Haryoto, H., Ftista, A.(2019). Aktivitas Antioksidan Ekstrak Etanol, Fraksi Polar, Semipolar dan Non Polar dari Daun Mangrove Kacangan (Rhizophora apiculata) dengan Metode DPPH dan FRAP. Jurnal Sains dan Kesehatan, 2 (2), 131-138.

[32] Johannes, E., Suhadiyah, S., Latunra, A. I.(2017). Bioaktivitas Ekstrak Daun Avicenia Marina Terhadap Pertumbuhan Bakteri Staphylococcus Aureus. Jurnal Ilmu Alam dan Lingkungan, 8 (15), 38-41.

[33] Firdaus, M., Prihanto, A. A., Nurdiani, R. (2013). Antioxidant and Cytotoxic Activity of Acanthus ilicifolius flower. Asian Pacific Journal Tropical Biomedicine, 3(1), 17-21. http://dx.doi.org/10.1016/S22211691(13)60017-9

[34] Hanin, N. N. F., Pratiwi, R.(2017). Kandungan Fenolik, Flavonoid dan Aktivitas Antioksidan Ekstrak Daun Paku Laut (Acrostichum aureum L.) Fertil dan Steril. Journal of Tropical Biodiversity and Biotechnology, 2, 51-56.

[35] Rahmi, H.(2017). Aktivitas Antioksidan dari Berbagai Buah-buahan di Indonesia. Jurnal AgrotekIndonesia,2(1),3438.https://journal.unsika.ac.id/index.php/agrotek/article/download/721/629

[36] Ramli, H. K., Yuniarti, T., Lita, N.P.S. N., Sipahutar, Y. H.(2020). Uji Fitokimia Secara Kualitatif Pada Buah dan Ekstrak Air Buah Mangrove. Jurnal Penyuluhan Perikanan dan Kelautan, 14 (1), 1-12. 